„Przekłady Literatur Słowiańskich”. T. 11, cz. 1, s. 1-4 ISSN 2353-9763 (wersja elektroniczna)

DOI https://doi.org/10.31261/PLS.2021.11.01.16

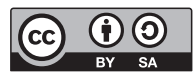

\title{
Pożegnanie Profesora Borisa Paternu
}

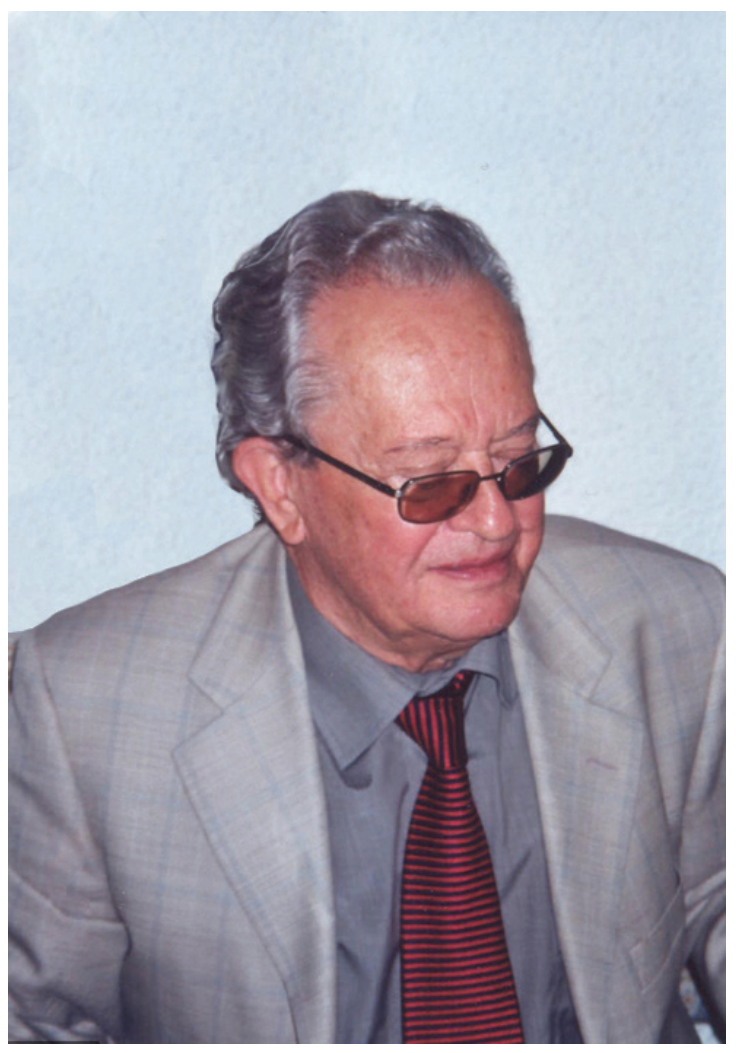

Boris Paternu (1926-2021)

Źródło: Archiwum Słoweńskiej Akademii Nauk i Sztuk (SAZU), https://www.sazu.si/clani/boris-paternu (dostęp: 16.12.2021). 
Dnia 26 listopada 2021 roku zmarł w Trieście w dziewięćdziesiątym szóstym roku życia akademik Boris Paternu - wybitny słoweński historyk i teoretyk literatury, członek Słoweńskiej Akademii Nauki i Sztuki (SAZU), znawca twórczości Francego Prešerna i dwudziestowiecznej poezji, emerytowany i zasłużony profesor Uniwersytetu w Lublanie. Zmarł w swoim domu w dniu, w którym planował wygłosić referat naukowy na posiedzeniu SAZU w Lublanie. Jego aktywność intelektualna i naukowa wzbudza szacunek i podziw w środowisku zarówno słoweńskim, jak i międzynarodowym. Wyjątkowość jego osobowości była doceniana przez naukowców i studentów, co znalazło odzwierciedlenie w przyznanych mu prestiżowych nagrodach naukowych i państwowych oraz w wypowiedziach byłych studentów publikowanych na Facebooku teraz, po jego śmierci. Wraz z jego odejściem słoweńskie literaturoznawstwo i kultura poniosły wielką stratę.

Profesor Boris Paternu pozostawił po sobie duży i znaczący dorobek naukowy, o czym świadczy obszerna bibliografia jego prac zebrana już w 1986 roku (por. Jože Munda: Bibliografija Borisa Paternuja: ob šestdesetletnici. „Slavistična revija” 1986, 34/3) oraz aktywna do końca obecność w słoweńskim życiu naukowym, udokumentowana licznymi książkami, rozprawami oraz wystąpieniami na konferencjach i sympozjach naukowych. Przedmiotem swych badań Profesor uczynił literaturę słoweńską od baroku do postmodernizmu, podejmował także niektóre zagadnienia starszego piśmiennictwa. W rozprawach badał i omawiał poszczególne dzieła w kontekście stylów i kierunków od reformacji do współczesności, co pozwalało mu dostrzegać pewne prawidłowości artystyczne, kulturowe i indywidualne. Jako badacz wchodził też z nimi w dialog, dysponując własnym bagażem poznawczym.

Szczególne miejsce w naukowej działalności Profesora zajmowała poezja Francego Prešerna, którą poddał twórczej reinterpretacji. W różnych okresach czasu jego studia nad nią odkrywały Słoweńcom niewypowiedziane prawdy o poecie i o nich samych. Należy tu wymienić książki: France Prešeren in njegovo pesniško delo, I-II $(1976,1977)$ - stanowiącą znaczącą podstawę do Kidričeve nagrade za znanost (1981), France Prešeren 1800-1849 (1994) oraz France Prešeren: poeta sloveno 1800-1849 (1999, wydaną w języku włoskim w Trieście). Wielu twierdziło, że swoimi studiami zbudował on pomnik Prešernowi, na co Profesor odpowiadał: „to nie ja, lecz on sam stworzył dzieło pomnikowe”. W Wieńcu sonetów pisał wszak Prešeren: „Poet tvoj nov Slovencem venec vije”.

Peter Kolšek w artykule opublikowanym 13 czerwca 2016 roku w „Delo”, w dziewięćdziesiątą rocznicę urodzin Profesora, przytoczył sentencje Tomasza Manna: poezja to „vesolje, stisnjeno v orehovo lupino”, i Borisa Paternu: „Poezija, če je dobra, ni za po kosilu", które wyjaśniają rodzajowe preferencje Profesora, a także jego stosunek do literatury i literaturoznawstwa. Choć swą karierę na- 
ukową rozpoczął od prozy narracyjnej i początków krytyki literackiej (Slovenska literarna kritika pred Levstikom, 1960 i Estetske osnove Levstikove literarne kritike, 1962), skupiał się przede wszystkim na poezji, widząc w niej syntezę odczuć i myśli. Pomimo to już pierwsze publikacje zapowiadały estetyczne podejście do literatury jako samodzielnej sztuki dającej przeżycie estetyczne w specyficznych warunkach, w jakich rozwijała się społeczna i duchowa historia Słowenii. Profesor był przekonany, że celem literaturoznawstwa jest odkrywanie znaczeń literatury jako sztuki słowa, czyli ewokowanego przez nią przeżycia estetycznego, poznawczego i emocjonalnego. Sprowadzenie literatury wyłącznie do celów utylitarnych uważał za podstawowy błąd wiedzy o literaturze.

Stosunek do literatury jako do autonomicznego fenomenu artystycznego wyjaśnia metodologię badawczą Profesora. Dzieło stanowiło dla niego wyzwanie poznawcze i estetyczne, do którego realizacji poszukiwał najwłaściwszych narzędzi badawczych zgodnie z aktualną wiedzą literaturoznawczą i humanistyczną. Dzięki temu odkrywał to, co nieznane lub niedocenione w przeszłości i w teraźniejszości, np. nowe odczytanie poezji Prešerna, poezję buntu czy wprowadzenie do poetyckiego panteonu Edvarda Kocbeka i Danego Zajca. Ważną cechą jego dorobku było spojrzenie komparatystyczne na literaturę słoweńską zarówno w kontekście słowiańskim, jak i europejskim. Porównania zmuszały go do typologizacji zjawisk literatury rodzimej w świetle podobieństw i różnic. W osiemdziesiątą rocznicę urodzin Borisa Paternu Marko Juvan napisał o nim, że jego dorobek stanowi pomost między klasyką a nowoczesnością. Niewątpliwie tak jest, ponieważ Profesor ogłaszał swoje badania na przestrzeni ponad 60 lat, przy czym pozostają one ciągle aktualne dzięki umiejętności łączenia potrzeb dzieła literackiego (co wynika z interpretacji immanentnej) z nowoczesnymi metodologiami literackimi. W opusie Profesora można odnaleźć twórcze wykorzystanie strukturalizmu, semiotyki i francuskiej krytyki tematycznej w celu odczytania głębszego znaczenia utworu. Dzieło nie służy potwierdzeniu słuszności metodologii, lecz metodologia ma stanowić nowy klucz do odczytania dzieła. Ta uniwersalna prawda nie zależy tylko od przyjętych narzędzi, chociaż w nie też jest wpisana świadomość czasu, paradygmat kulturowy.

Boris Paternu był nie tylko wybitnym badaczem, lecz również doskonałym organizatorem życia naukowego w perspektywie międzynarodowej, co łączyło się z jego pracą badawczą. Był między innymi inicjatorem cyklicznych konferencji międzynarodowych Obdobja, które po raz pierwszy zorganizował w 1978 roku i które są kontynuowane do dzisiaj; współredaktorem renomowanego czasopisma „Slavistična revija” i publikacji pokonferencyjnych Obdobja; członkiem Rady Naukowej Enciklopedije Slovenija; organizatorem międzynarodowego sympozjum o Prešernie w Kranju w 1999 roku; członkiem nowego zespołu redakcyjnego Brežinskih spomenikov. W dowód uznania został 
w 1979 roku powołany na członka korespondenta Słoweńskiej Akademii Nauki i Sztuki, a w 1985 - na członka rzeczywistego.

Profesor związany był z trzema miastami: z Kranjem — od piętnastego roku życia do studiów w Lublanie, z miastem tym łączyła go biografia Prešerna i pochodzenie jego matki z rodziny Čopów (protoplasta Matija Čop był przyjacielem Prešerna i łącznikiem z polską literaturą); z Lublaną - gdzie mieszkał, studiował, a od 1961 roku do odejścia na emeryturę w 1994 roku wykładał na Wydziale Filozoficznym Uniwersytetu w Lublanie; z Triestem — nad Zatoką Triestańską, oknem na świat Słowenii, gdzie mieszkał wraz z żoną Mariją Pirjevec i pracował naukowo do końca życia.

Poznałam osobiście Profesora Paternu w 1976 roku. Zawdzięczam mu dwutorowość mojej kariery naukowej: słowenistyczną i polonistyczną. To on zainteresował mnie literaturą i kulturą słoweńską, zainspirował do jej badania, wierzył w moje możliwości intelektualne, pomagał, gdy była taka potrzeba. Dzięki niemu stałam się słowenistką. Dziękuję. Nie byłam studentką Profesora, choć słyszałam wiele jego wystąpień, „ekspresywno-poetyckich”, jak je określił Peter Kolšek. Muszę jednak podkreślić fakt, że w czasie naszych ponad pięćdziesięcioletnich kontaktów naukowych zauważyłam, jak bardzo inspirujący dla innych miał umysł $i$ jak dobrze potrafił dostrzegać wartość drugiego. Tacy ludzie zdarzają się rzadko, są to „velikani”, jak pisał o Prešernie i Cankarze słoweński poeta awangardowy Srečko Kosovel.

Wraz ze śmiercią Profesora Borisa Paternu ogromną stratę poniosła słoweńska kultura, jego koledzy, przyjaciele oraz miłośnicy literatury. Brak ten w wielu na długo pozostanie trudną do przeżycia żałobą.

Bożena Tokarz 